\title{
Individual membership
}

Membership in the African Studies Association membership is open to scholars, students, and professionals from around the world who have an interest in Africa.

ASA members enjoy many benefits, including:

- A subscription to African Studies Review, a multi-disciplinary scholarly journal, which publishes original research and analyses of Africa and book reviews, as well as a digital subscription to History in Africa*, an annual journal that features textual analysis and criticism, historiographical essays, bibliographical essays, archival reports and articles on the role of theory and non-historical data in historical investigation

- A discounted registration fee to attend the Annual Meeting

- A listing in the ASA Online Membership Directory with an advanced search feature to easily locate ASA colleagues and individuals

- An opportunity to vote to elect officers and members of the Board of Directors

- An opportunity to serve on ASA Committees

- The ability to nominate individuals for the Distinguished Africanist Award

*Print copies of History in Africa are available to members for purchase at the additional price indicated below.

Membership can be purchased securely online at http://journals.cambridge.org/ ASAMBR, or by contacting the member services team at Cambridge University Press. Email: USmemberservices@cambridge.org; Phone (845) 353 7500; Fax (845) 3534141

Membership in the ASA is on a calendar year basis.

Membership (Income equivalent to $\$ 50,000$ and above)

$\$ 180.00$ or $\mathrm{f} 111$ or $€ 137$

Membership (Income equivalent to $\$ 50,000$ and above) + print subscription to HIA $\$ 230.00$ or $\mathrm{f} 143$ or $€ 175$

Membership (Income equivalent to \$49,999 and below)

$\$ 115.00$ or $€ 71$ or $€ 87$

Membership (Income equivalent to $\$ 49,999$ and below) + print subscription to HIA

$\$ 165.00$ or $\mathrm{f} 102$ or $€ 125$

Retiree Membership

$\$ 100.00$ or $£ 62$ or $€ 76$

Retiree Membership + print subscription to HIA

$\$ 150.00$ or $£ 93$ or $€ 114$

Student Membership (please send a copy of a valid ID)

$\$ 70.00$ or $£ 43$ or $€ 53$

Student membership + print subscription to HIA (please send a copy of a valid ID)

$\$ 120.00$ or $€ 74$ or $€ 91$ 


\section{Cambridge Journals Online}

For further information about the journal, please go to the publisher's journal Web site at journals.cambridge.org/HIA 